\title{
Heterologous fibrin sealant derived from snake venom: from bench to bedside - an overview
}

\author{
Rui Seabra Ferreira Jr ${ }^{1,2,4^{*}}$, Luciana Curtolo de Barros ${ }^{2}$, Luciana Patrícia Fernandes Abbade ${ }^{3}$, \\ Silvia Regina Catharino Sartori Barraviera ${ }^{3}$, Maria Regina Cavariani Silvares ${ }^{3}$, Leticia Gomes de Pontes ${ }^{1,2}$, \\ Lucilene Delazari dos Santos ${ }^{1,2}$ and Benedito Barraviera ${ }^{1,2}$
}

\begin{abstract}
Hemostatic and adhesive agents date back to World War II, when homologous fibrin sealant came onto scene. Considering that infectious diseases can be transmitted via human blood, a new heterologous fibrin sealant was standardized in the 1990s. Its components were a serine protease (a thrombin-like enzyme) extracted from the venom of Crotalus durissus terrificus snakes and a fibrinogen-rich cryoprecipitate extracted from the blood of Bubalus bubalis buffaloes. This new bioproduct has been used as a coagulant, sealant, adhesive and recently as a candidate scaffold for mesenchymal stem cells and bone and cartilage repair. This review discusses the composition of a new heterologous fibrin sealant, and cites published articles related to its preclinical applications aiming at repairing nervous system traumas and regenerating bone marrow. Finally, we present an innovative safety trial I/II that found the product to be a safe and clinically promising candidate for treating chronic venous ulcers. A multicenter clinical trial, phase II/III, with a larger number of participants will be performed to prove the efficacy of an innovative biopharmaceutical product derived from animal venom.
\end{abstract}

Keywords: Fibrin sealant, Snake venom, Cryoprecipitate coagulum, Thrombin-like enzyme, Buffaloes

\section{Background}

The first research studies on hemostatic agents and adhesives date back to World War II, when fibrin glue was proposed. In that time, a mixture of human fibrinogen and thrombin was applied to the affected aera. In 1970, given that the basic principles for extracting fibrinogen-rich cryoprecipitate and coagulation factors were already known, the concept of fibrin glue was reevaluated. Since that point, a new adhesive has been standardized with the following composition: fibrinogen-rich human cryoprecipitate, bovine thrombin and calcium chloride as the diluent. This sealant was successfully commercialized for years [1,2].

In 1978, the U.S. Food and Drug Administration (FDA) suspended its commercialization due to the

\footnotetext{
* Correspondence: rseabra@cevap.unesp.br

${ }^{1}$ Graduate Program in Tropical Diseases, Botucatu Medical School, São Paulo State University (UNESP - Univ Estadual Paulista), Botucatu, SP, Brazil ${ }^{2}$ Center for the Study of Venoms and Venomous Animals (CEVAP), São Paulo State University (UNESP - Univ Estadual Paulista), Botucatu, SP, Brazil Full list of author information is available at the end of the article
}

possibility of the transmission of infectious diseases, carried via products derived from human blood $[3,4]$.

In order to overcome these difficulties, in the 1990s the Center for the Study of Venoms and Venomous Animals (CEVAP) at São Paulo State University (UNESP) initiated studies to achieve the standardization of a new heterologous fibrin sealant (HFS). After several experiments, a new sealant was proposed, which was composed of a fibrinogen-rich cryoprecipitate extracted from the blood of the buffalo Bubalus bubalis in association with a serine protease (a thrombin-like enzyme) extracted from Crotalus durissus terrificus venom [5-8].

The active ingredient of this new heterologous fibrin sealant mimics the final step of the coagulation cascade. So, a thrombin-like enzyme acts upon the fibrinogen molecule, transforming it into fibrin monomers that polymerize in the presence of calcium to form a stable clot with adhesive, hemostatic and sealant effects $[8,9]$.

Figure 1 shows the blood-clotting cascade in three different pathways, with human thrombin, bovine thrombin 
Factor XIII

(in tissue and plasma)

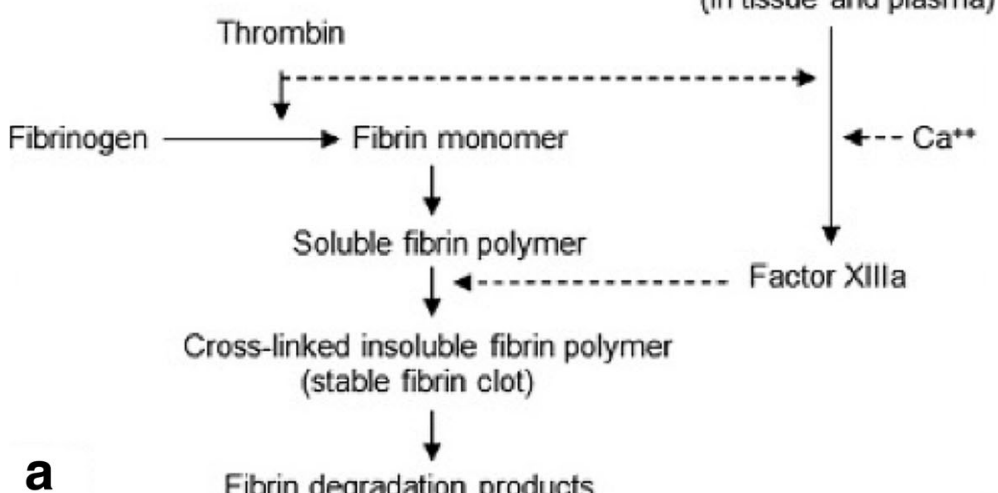

Fibrin degradation products
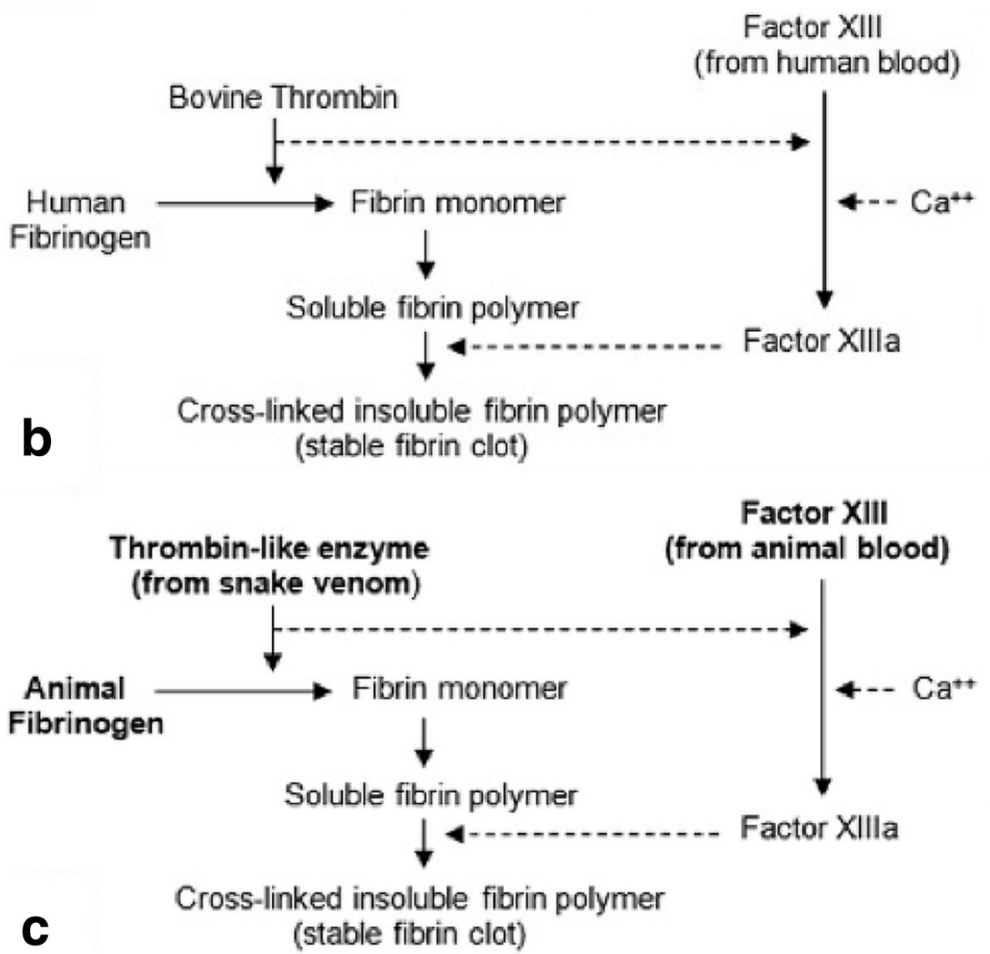

Fig. 1 a The final common pathway of the human blood-clotting cascade. $\mathbf{b}$ The effect of bovine thrombin on human fibrinogen. $\mathbf{c}$ The effect of a serine protease (thrombin-like enzyme) extracted from snake venom on animal fibrinogen forming a stable fibrin polymer. Reprinted from "A new fibrin sealant from Crotalus durissus terrificus venom: applications in medicine" by LC Barros et al., J Toxicol Environ Health B Crit Rev, 2009, 12(8), 553-71 [9]. Copyright by Taylor \& Francis LLC (http://www.tandfonline.com). Reprinted with permission

and serine protease extracted from Crotalus durissus terrificus venom [9]. Figure 2 shows a stable network of fibrin formed from a mixture of animal cryoprecipitate with serine protease extracted from snake venom, observed by electron microscopy [10].

\section{Composition of the heterologous fibrin sealant Fraction I: serine protease (gyroxin) Molecular structure}

The composition of the venom from Crotalus durissus terrificus snakes is complex and constituted of enzymes, toxins and peptides. Since the 1980s, several authors have studied, isolated and purified serine proteases including gyroxin, a thrombin-like enzyme extracted from the venom of Crotalus durissus terrificus [11-15]. Electrophoretic analysis verified that this enzyme is a single-chain type, with an estimated molecular mass of $34 \mathrm{kDa}$ and maximum stability at $\mathrm{pH} 8.0$, and does not present alteration by freezing or thawing. Its maximum enzymatic activity occurs at $\mathrm{pH} 4.0$, being resistant to treatment at $40^{\circ} \mathrm{C}$ for $15 \mathrm{~min}$. 


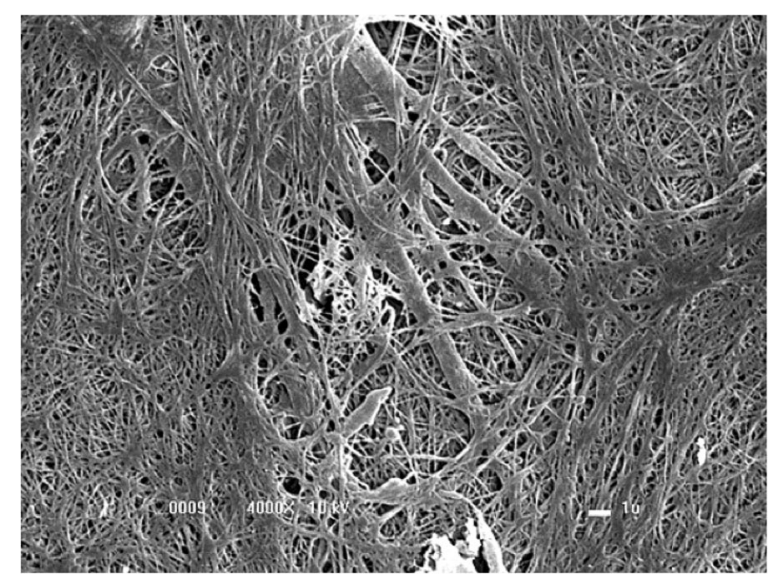

Fig. 2 Stable fibrin network visualized in an electron microscope $(4,000 \times)$. Reprinted from "A new fibrin sealant as a three-dimensional scaffold candidate for mesenchymal stem cells" by VPO Gasparotto et al., Stem Cell Res Ther, 2014, 5(3), 78 [10]. Copyright by VPO Gasparotto et al. Reprinted with permission

Theoretical molecular modeling of this serine protease extracted from Crotalus durissus terrificus venom was accomplished via the program Modeller and visualization of the model by the program PyMOL. In this manner, Fig. 3 shows the structural model, which was revealed as a monomeric globular structure, presenting two $\alpha$-helix structures (red) containing the residues 146-152 and 215-227, two $\beta$-barris structures formed by six antiparallel sheets and loops (green), five disulfide bridges (blue) and a catalytic triad (orange) $[16,17]$.

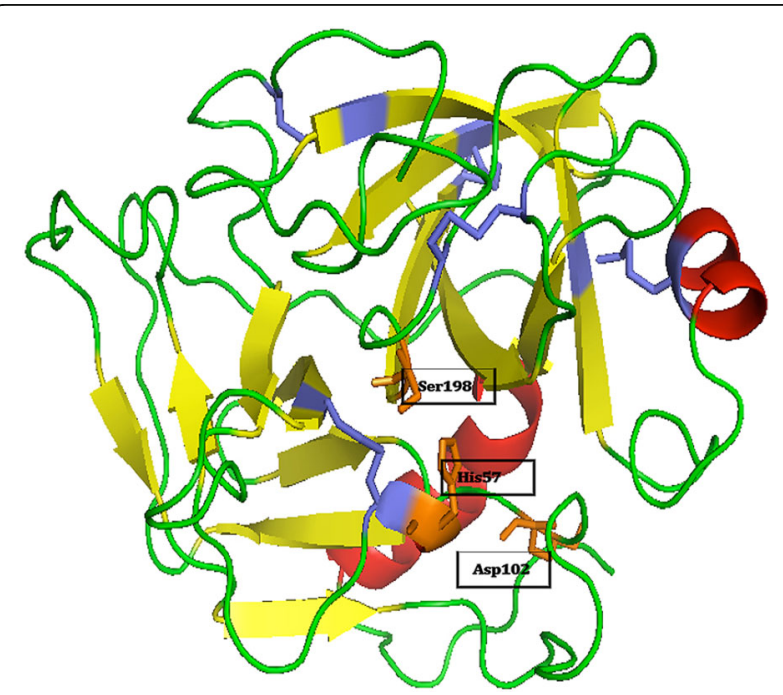

Fig. 3 Theoretical molecular modeling of gyroxin accomplished using Modeller and PyMOL programs. This serine protease has two a-helix structures (red) containing the residues 146-152 and 215227, two $\beta$-barris structures formed by six antiparallel sheets and loops (green), five disulfide bridges (b/ue) and a catalytic triad (orange)
Due to its enzymatic activity, similar to thrombin, the serine protease acts on human and animal fibrinogen, cleaving the $\alpha$-chain proximal to the $\mathrm{N}$-terminal. The resultant fibrin monomers were polymerized in an intense stable network (Fig. 2) in contrast to that traditionally produced by thrombin.

\section{Isolation and structural elucidation}

Venom from Crotalus durissus terrificus snakes (Fig. 4) was milked at CEVAP and pooled according to good manufacturing practices (GMP). All the snakes are microchipped to ensure the traceability of the venom lots used in the composition of heterologous fibrin sealant. After filtration and lyophilization, the venoms are stored in the Venoms Bank of CEVAP.

To isolate the serine protease (gyroxin), a low-pressure liquid chromatography system was employed, specifically the model Äkta Pilot ${ }^{\oplus}$ (GE HealthCare Life Science, Sweden) and the software Unicorn ${ }^{\odot} 6.3$ controlled the data acquisition. All reagents and salts utilized were of HPLC grade, and the Milli-Q water used was obtained in a Milipore ${ }^{\varpi}$ ultra-purifier (Fig. 5).

Fifteen grams of lyophilized venom from Crotalus durissus terrificus was suspended in $200 \mathrm{~mL}$ of the buffer 0.05 $\mathrm{M}$ Tris- $\mathrm{HCl} \mathrm{pH}$ 7.4. This was applied in an AxiChrom $100 / 300^{\circ}$ chromatographic column (100 mm x $300 \mathrm{~mm} \mathrm{x}$ $350 \mathrm{~mL}$ ) (GE HealthCare Life Science, Sweden) encased with affinity resin Benzamidine Sepharose $6 \mathrm{~B}^{\circ}$ (GE HealthCare Life Science, Sweden) previously equilibrated with $525 \mathrm{~mL}$ of $0.05 \mathrm{M}$ Tris-HCl pH 7.4 buffer (buffer 1). The sample was eluted with $525 \mathrm{~mL}$ of $0.05 \mathrm{M}$ Tris- $\mathrm{HCl}$ $\mathrm{pH} 7.4$ (buffer 1), followed by $525 \mathrm{~mL}$ of $0.05 \mathrm{M}$ Tris$\mathrm{HCl} / 0.5 \mathrm{M} \mathrm{NaCl} \mathrm{pH} \mathrm{7.4} \mathrm{(Buffer} \mathrm{2)} \mathrm{and} \mathrm{1,050} \mathrm{mL} \mathrm{of} \mathrm{gly-}$ cine $0.02 \mathrm{M} \mathrm{pH} 3.2$ (buffer 3). The flow utilized was 10 $\mathrm{mL} / \mathrm{min}$ and collected $25 \mathrm{~mL} /$ tube. The elution was monitored at an absorbance of $280 \mathrm{~nm}$.

This purification process generates a single fraction whose purity is evaluated by $\mathrm{N}$-terminal sequences (EDMAN) and mass spectrometry.

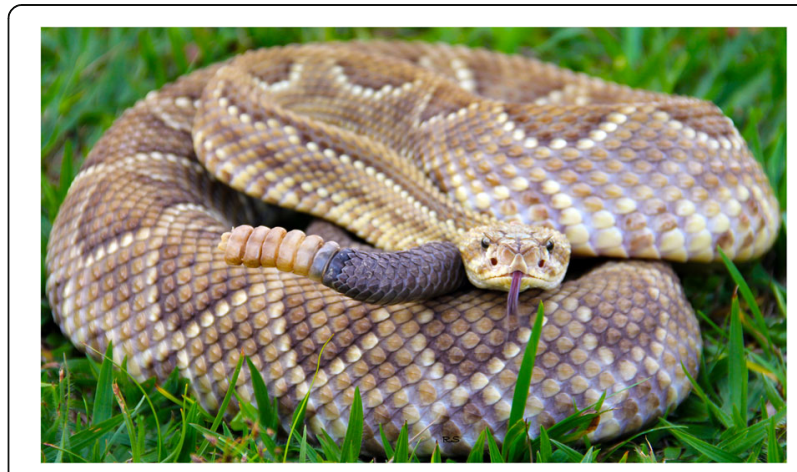

Fig. 4 Crotalus durissus terrificus snake 


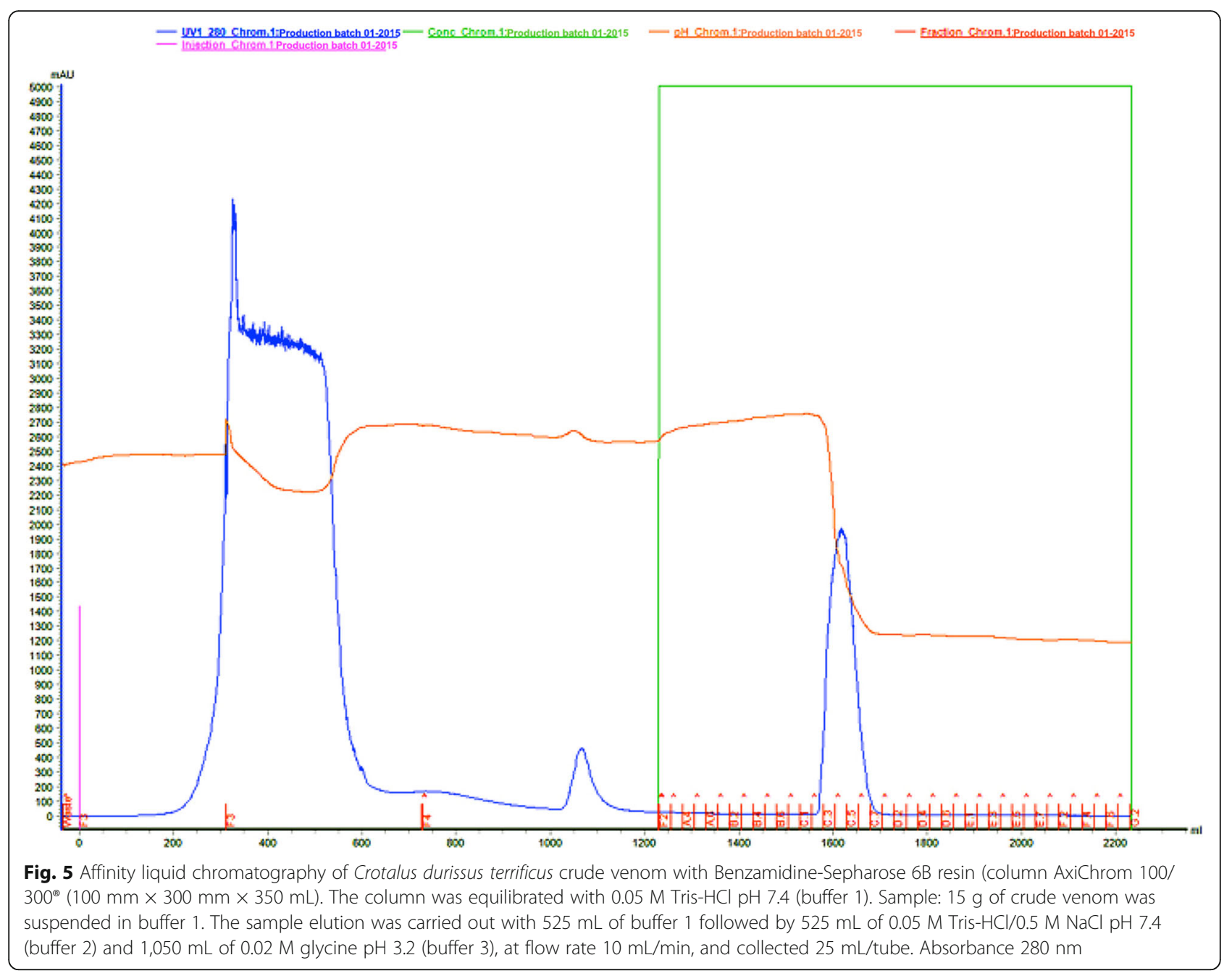

Figures 6 and 7 show, respectively, the comparison of $\mathrm{N}$-terminal sequence of gyroxin with other thrombinlike snake toxins and their molecular mass by ESI mass spectrometry.

\section{Biological activity}

In 2011, Barros et al. [9, 18] evaluated the coagulant activity of a serine protease isolated from Crotalus durissus terrificus venom, which was able to induce the formation of a fibrin network and consequently the formation of a stable clot at different concentrations.

Coagulant activity was studied at three different $\mathrm{pH}$, namely: 4.0, 6.0 and 7.4. At each of them, the minimum coagulant dose (MCD) was verified and defined as the quantity at which a certain enzyme is capable of coagulating $200 \mu \mathrm{L}$ of plasma in $60 \mathrm{~s}$ [15]. At $\mathrm{pH} 4.0$, the MCD was $0.037 \mu \mathrm{g} / \mu \mathrm{L}$ of plasma, versus $0.015 \mu \mathrm{g} / \mu \mathrm{L}$ at $\mathrm{pH} 6.0$ and $0.021 \mu \mathrm{g} / \mu \mathrm{L}$ at $\mathrm{pH}$ 7.4. Table 1 and Fig. 8 display the MCD at $\mathrm{pH}$ 7.4.
The serine protease coagulant activity at $\mathrm{pH} 7.4$ was also confirmed through dose-dependent activity evaluated to obtain the MCD. For potential regression analysis, the MCD was determined at $0.021 \mu \mathrm{g} / \mu \mathrm{L}$ of human plasma, as shown in Fig. 9.

It must be emphasized that the statistical analysis did not present a difference in the comparison of serine protease activity at $\mathrm{pH} 6.0$ versus $\mathrm{pH}$ 7.4. These results lead to the conclusion that the best activity of the enzyme is found at between $\mathrm{pH} 6$ and 7.4, values close to the optimum $\mathrm{pH}$ for blood-thrombin activity, which is 7.3 and varies in blood between 7.35 and 7.45 [18].

\section{Fraction II: cryoprecipitate}

Cryoprecipitate is the insoluble fraction, a cold precipitate of frozen fresh plasma (FFP) from Bubalus bubalis buffalos. It contains fibrinogen, factor VIII (F VIII), Willebrand factor (F vW), factor XIII (F XIII) and fibronectin $[19,20]$. It must contain at least 80 units of factor VIII and between 150 and $250 \mathrm{mg}$ of fibrinogen. Each 


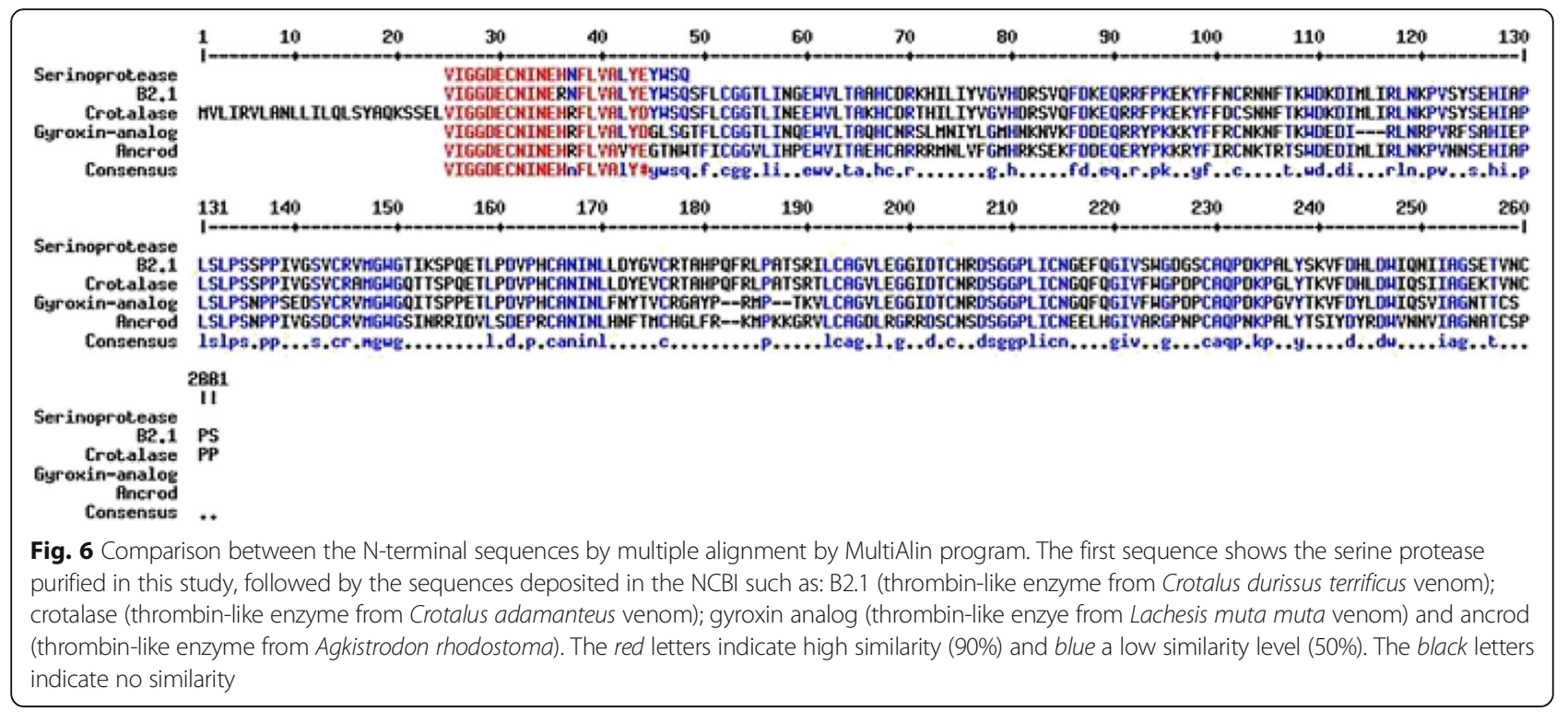

unit has a volume from 10 to $20 \mathrm{~mL}$, which must be stored at $-20^{\circ} \mathrm{C}$ and has a shelf life of one year.

In 1995, Iuan et al. [5] proposed for the first time a new fibrin sealant constituted of a serine protease extracted from the venom of Crotalus durissus terrificus and human cryoprecipitate. The new product was compared with the commercial sealant in relation to the repair of sciatic nerves in Wistar rats. The anatomopathological analyses found similar results between the two products. Aiming at preventing infectious diseases transmitted by human
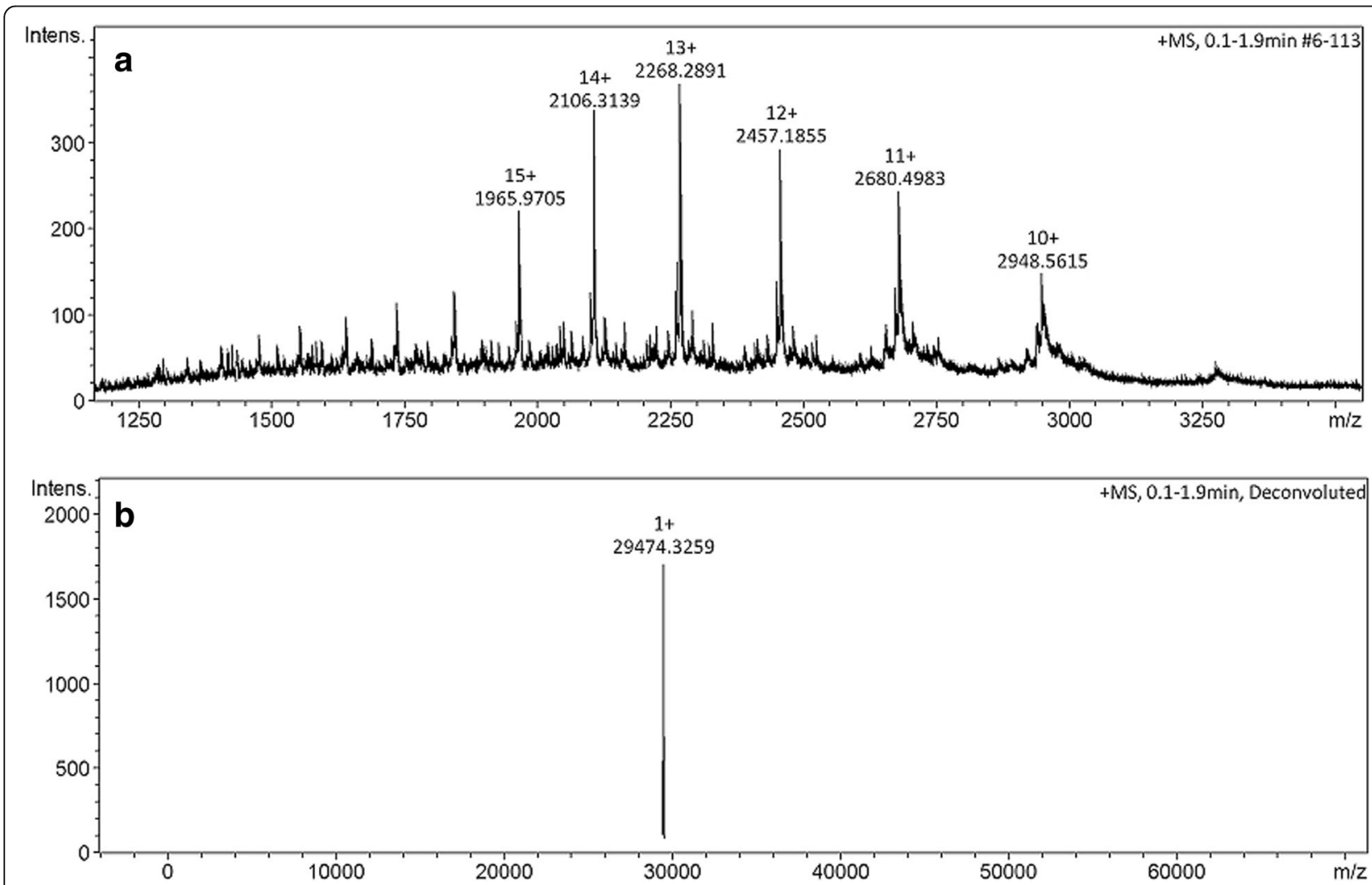

Fig. 7 LC-MS by ESI-ToF mass spectra (MicroQ-ToF III, Bruker Daltonics ${ }^{\oplus}$ ). a Different protonated forms of gyroxin from Crotalus durissus terrificus. $\mathbf{b}$ Deconvoluted mass spectrum showing $[\mathrm{M}+\mathrm{H}]^{+1}=29.472 \mathrm{~m} / \mathrm{z}$. Molecular mass of this serine protease is $29.473 \mathrm{Da}$ 
Table 1 Serine protease concentrations employed to evaluate the clotting time, the mean of three measures, the standard deviation and standard error of the mean for a 95\% confidence interval at $\mathrm{pH} 7.4$

\begin{tabular}{llcc}
\hline Concentration $(\mu \mathrm{g})$ & Mean (seconds) & Standard deviation & $\begin{array}{l}\text { Standard } \\
\text { error of } \\
\text { the mean }\end{array}$ \\
\hline 3 & 84 & \pm 3.60 & 2.08 \\
5 & 50.7 & \pm 0.57 & 0.33 \\
10 & 32.7 & \pm 0.57 & 0.33 \\
15 & 20 & \pm 0.0 & 0.0 \\
20 & 14.7 & \pm 0.57 & 0.33 \\
25 & 13.3 & \pm 0.57 & 0.33 \\
\hline
\end{tabular}

blood, Thomazini-Santos et al. [21] in 1998 proposed for the first time to replace fibrinogen extracted from human blood with that from buffaloes. These same authors [21] evaluated the cryoprecipitate level of diverse animals and compared them with that extracted from human blood. They observed that buffaloes presented the highest fibrinogen levels, as shown in Table 2. Due to the good performance of the cryoprecipitate extracted from buffalos, these animals have been selected as the ideal donors.

In Brazil, the following four buffalo breeds are recognized by the Brazilian Association of Buffalo Breeders: mediterrâneo, murrah, jafarabadi (river buffalo) and carabao (swamp buffalo). The murrah breed, Bubalus bubalis, of Indian origin has been raised at the Lageado Experimental Farm, UNESP campus in Botucatu, for more than 30 years [22].

In order to ensure that this bioproduct contains no substance foreign to the human body, it is necessary to select and certify the donors. Therefore, sanitary management is mandatory for good economic results, which includes the following actions: annual vaccination against foot-andmouth disease, brucellosis and rabies; systematic deworming; measures for hygiene and asepsis; practices of isolation and quarantine; protection of animals against vectors of transmissible diseases; diagnostic serological tests against brucellosis and leptospirosis; an annual hypersensitivity test against tuberculosis (tests of tuberculinization and of Mantoux or PPD); as well as frequent clinical exams performed by an experienced veterinary physician. These actions are recommended by the Department of Animal Health of the Secretariat for the Defense of Agribusiness and Livestock Raising in the Ministry of Agriculture, Livestock and Food Supply (MAPA) and by the World Health Organization, and are in continuous execution by the abovementioned team [23-29].

Despite all these precautions, these animals can still pose a risk to human health due to transmission of spongiform encephalopathies (TSEs), also known as prion diseases, or as "mad cow" [29]. They are fatal neurodegenerative diseases that include scrapie in sheep, a bovine spongiform encephalopathy (BSE) and Creutzfeldt-Jakob disease (CJD) in humans. In buffalos, the transmission can occur through the consumption of previously infected tissue that is used in the feed manufacturing, particularly nerve tissue. In suspicious cases, the necropsy becomes the highest priority, followed by anatomical-pathological analysis. Researchers at CEVAP in partnership with the Center for Stable Environmental Isotopes, in the Botucatu Biosciences Institute of UNESP, developed a globally pioneering technique of isotopic tracers based on the dosing of carbon isotopes $\left({ }^{13} \mathrm{C}\right)$ and nitrogen $\left({ }^{15} \mathrm{~N}\right)$ in sheep and buffaloes [30,31]. After its standardization, this technique was tested in animals of the abovementioned herd, showing an absence of animal protein ingestion, which indirectly indicates that the buffalo donors of cryoprecipitate were potentially free of mad cow disease.

The growing concern with the rapid identification and resolution of sanitary problems in livestock has increased the interest in the study of biomarkers. Recent research has shown that the quantification of acute-phase proteins in blood can offer useful information for early diagnosis, prognosis and monitoring of diseases [32]. These proteins are considered not only potential indicators of inflammatory disease or contagious infections, but also an important tool in slaughterhouses to ensure food safety [33, 34].

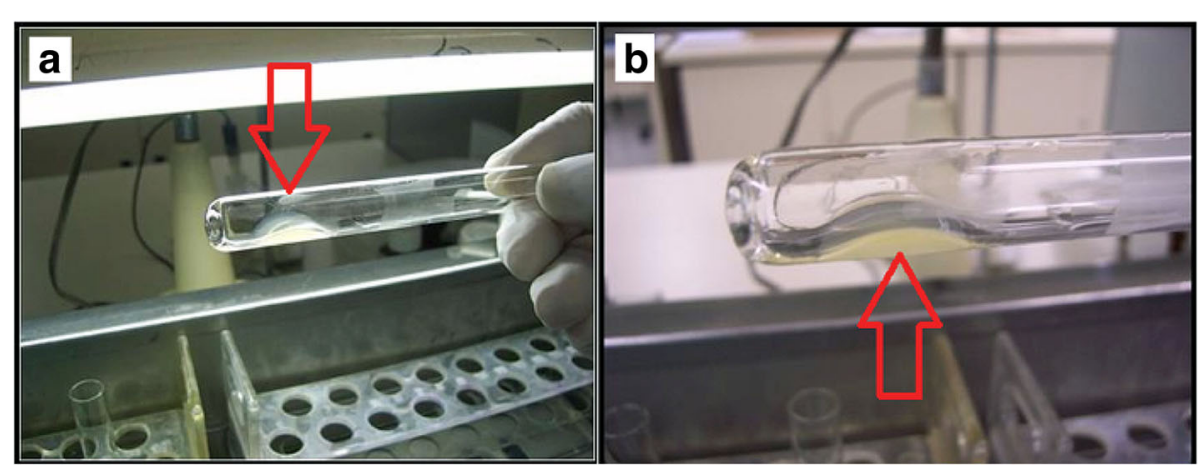

Fig. 8 Coagulant activity: a fibrin clot formed after incubation of human plasma with serine protease; $\mathbf{b}$ detail of fibrin network 


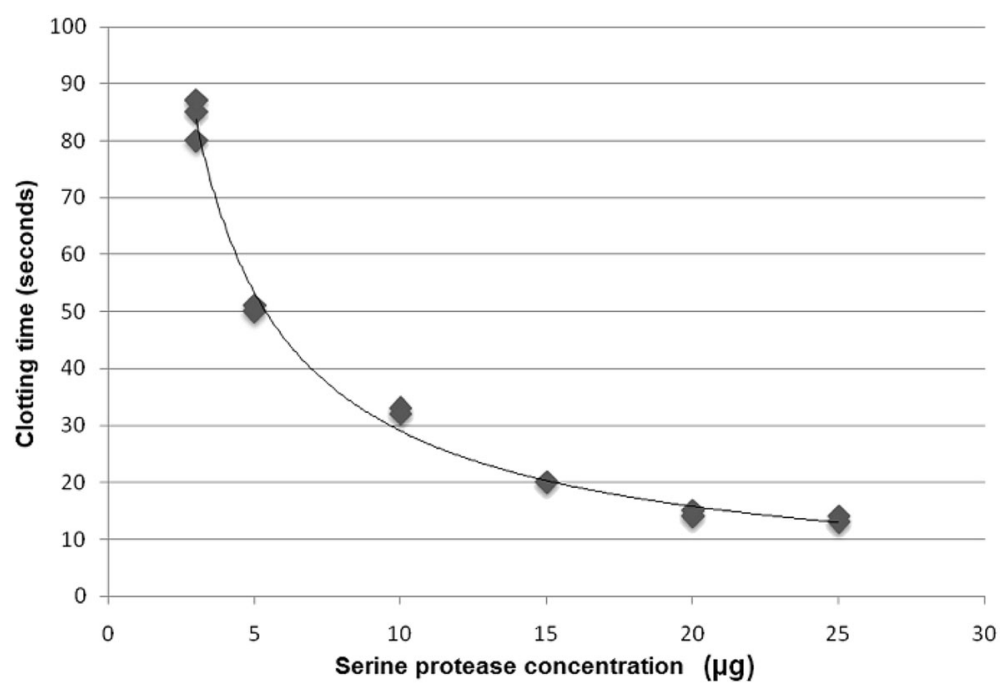

Fig. 9 Evaluation at $\mathrm{pH} 7.4$ of the minimum coagulant dose (MCD) of the serine protease by potential regression analysis $y=220.13 x^{-0,879}, R^{2}=0.9899$

The concentrations of these proteins, which remain circulating for long periods, depend on the severity of the dysfunction. Therefore, their quantification is an essential tool to evaluate the presence and severity of the inflammatory process, in contrast to the cytokines that remain circulating for short periods and whose measurement is onerous [35].

The first response of the organism to immunological stress is a non-specific release of cytokines that are mediators in the variation of acute-phase proteins [34, 35]. Through the influence of interleukins 1 and 6 (IL-1, IL6 ) and of tumor necrosis factor (TNF- $\alpha$ ), the hepatic cells augment or diminish the synthesis and the secretion of certain proteins. The response occurs immediately after a lesion or disease, declining within one or two days. The acute-phase proteins can be divided into two groups: negative and positive. The negative proteins are those that diminish the concentration when an acute-phase response occurs - and include albumin and transferrin, while the positive ones have their level elevated when there is an acute-phase response. In the latter case we have an increase in circulating C-reactive protein (CRP), glycoprotein-1 acid, antitrypsin-1, antichemotrypsin-1, serum amyloid A, ceruloplasmin, haptoglobin, macroglobin-2, fibrinogen and component $\mathrm{C}_{3}$ of the complement system [34, 36, 37].

For ruminants, haptoglobin has been described as the most important and reliable marker [32, 33]. Thus, the standardization of acute-phase biomarkers (fibrinogen and haptoglobin) and the clinical evaluation prior to blood donation permit the presumptive diagnosis of possible diseases and the removal of the donor animal to ensure the extraction of a safe bioproduct.

A rigorous protocol was applied in order to maintain biosecurity and the traceability of cryoprecipitate, as follows:

- In the herd of buffalos:

$>$ microchipping permitting traceability $a$ posteriori;

$>$ annual vaccination control against rabies, brucellosis and foot-and-month disease;

$>$ application and annual evaluation of the tuberculin;

$>$ control of spongiform encephalopathy (mad cow disease) by means of isotopic analysis; $>$ nonspecific presumptive diagnosis of diseases for selection of ideal donors by means of haptoglobin and fibrinogen biomarkers.

- In blood collection:

$>$ utilizing quadruple bag with filters in a line similar to those employed for humans;

$>$ transporting the bags with blood in refrigerated boxes to the processing laboratory;

$>$ applying techniques to evaluate fibrinogen levels and the factors V, VIII and von Willebrand;

Table 2 Comparison of fibrinogen concentration in mg\% in human, bovine, equine, ovine and buffalo blood

\begin{tabular}{lllll}
\hline Mean fibrinogen concentration in cryoprecipitate $(\mathrm{mg} \%)$ & & & \\
\hline Human $(N=12) \mathrm{G} 1$ & Bovine $(N=9) \mathrm{G} 2$ & Equine $(N=10) \mathrm{G} 3$ & Ovine $(N=10) \mathrm{G} 4$ & Buffalo $(N=7) \mathrm{G5}$ \\
\hline $375.50 \pm 70.95$ & $218.33 \pm 9.76$ & $240.80 \pm 72.03$ & $267.70 \pm 25.42$ & $664.00 \pm 11.96$ \\
\hline
\end{tabular}

Statistics: $\mathrm{G} 1 \times \mathrm{G} 2 \times \mathrm{G} 3 \times \mathrm{G} 4 \times \mathrm{G} 5, \mathrm{~F}=120.26, p<0.001, \mathrm{G} 5>\mathrm{G} 1>(\mathrm{G} 2=\mathrm{G} 3=\mathrm{G} 4)$ 


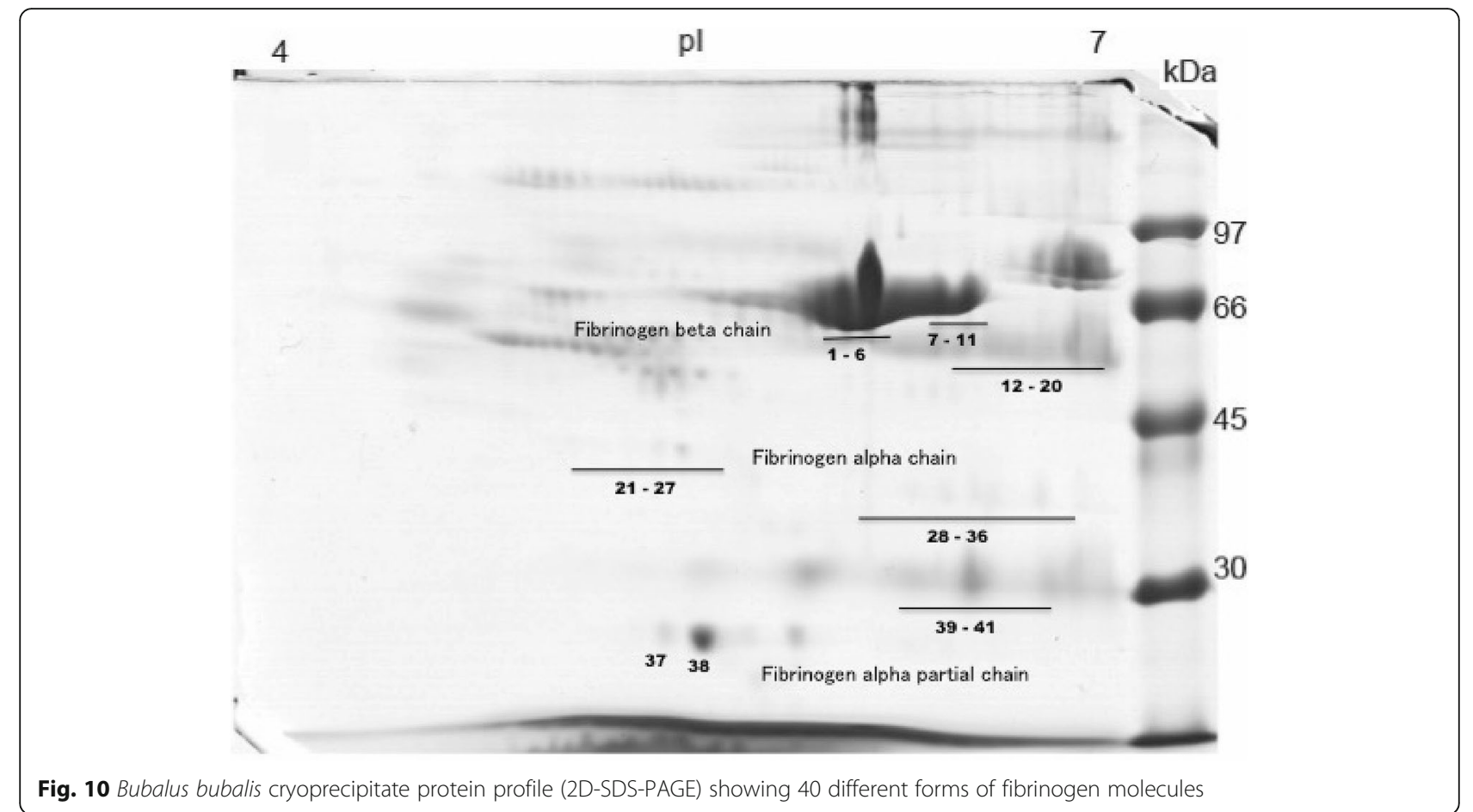

$\triangleright$ preventing possible contaminations of the bags utilizing for quality control animal blood culture and of the bags in $\mathrm{Bactec}^{\circ}$ for aerobic and anaerobic bacteria and Bactec Myco-F Lytic ${ }^{\circ}$ for fungi.

Finally, analytical methods with singular characteristics, such as higher sensitivity, resolution and reproducibility were employed with a clinical proteomic approach [38]. Two-dimensional electrophoresis (2D) was used for isolating and identifying proteins by means of their molecular masses and isoelectric points in polyacrylamide gel, and electrospray-type mass spectrometry was used for sequencing peptides and proteins and identifying their biological function. Figure 10 shows the total protein profile of cryoprecipitate extracted from buffalos presenting the different forms of fibrinogen, evidenced for better visualization, since this protein is the main molecule responsible for stable fibrin clot formation. There are three observable classes of fibrinogen denominated: $\beta$-chain fibrinogen, from $\alpha$ and partial forms of $\alpha$-chain fibrinogen, totaling 40 different forms of the molecule.

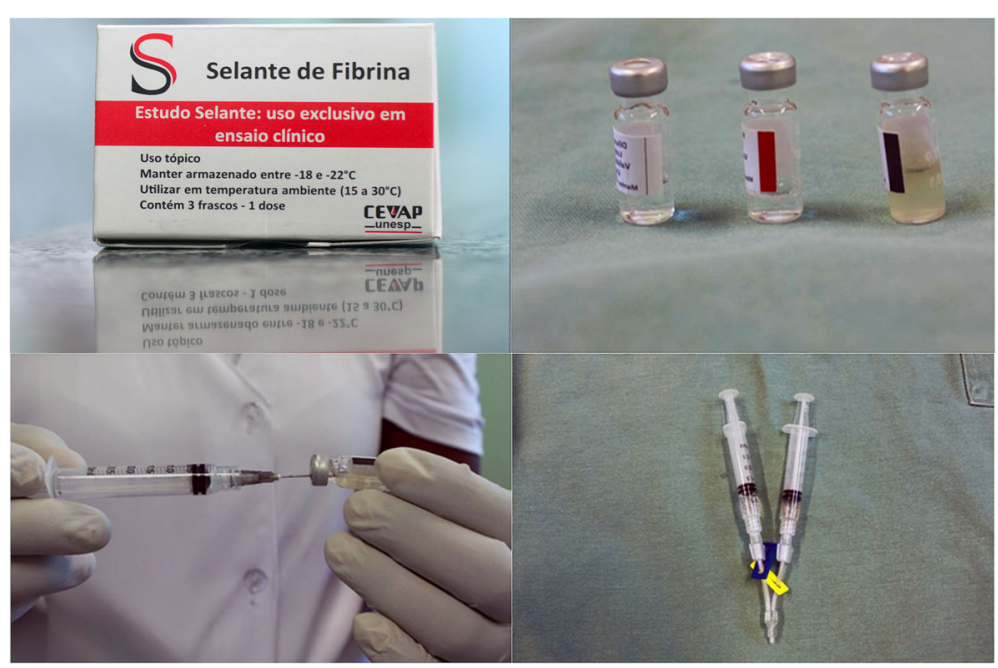

Fig. 11 Packaging and vials approved only for clinical research use 


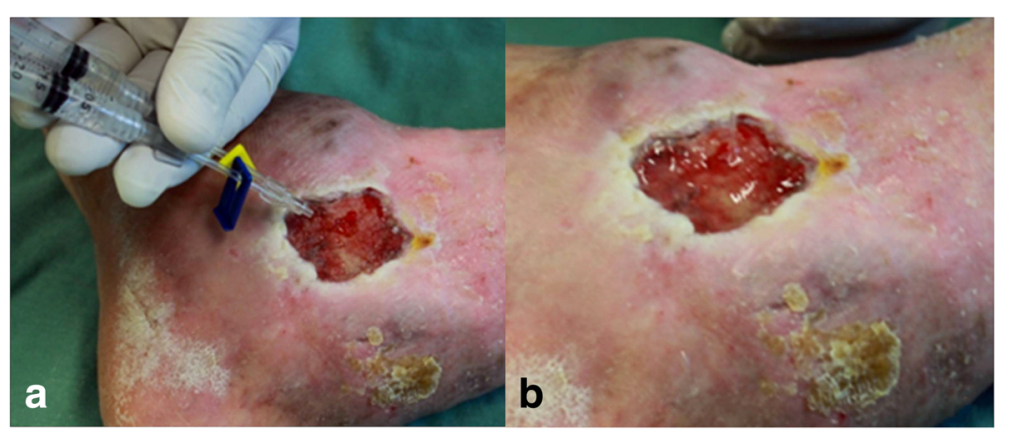

Fig. 12 a Application of the product utilizing a double-outlet syringe with mixer at its end. b Polymerized product covering an ulcer

In sum, the cryoprecipitate extracted to be applied as a new heterologous fibrin sealant standardized by CEVAP is a product that is safe and free from undesirable substances. The formulation, as well as its storage, handling and dosage are described in detail in the internationally required patents (PCT/BR2015/000065 and PCT/BR2015/000064) [39].

\section{The human use of heterologous fibrin sealant}

The heterologous fibrin sealant, widely studied experimentally, is now in a phase I/II clinical trial for the treatment of chronic venous ulcers. Herein, we briefly describe the methodology utilized for manufacturing this new biomedicine that possesses vast potential to replace the human constituents utilized in commercial sealants currently available on the market. This product has undergone more than 20 years of development and due to its novelty and originality, it represents a success story in the context of World Toxinology, mostly in the southern hemisphere.

Until the present, two phase I/II clinical trials (called Sealant I and Sealant II) have been proposed for evaluating the treatment of chronic venous ulcers. For this purpose, four batches of sealant were produced for application in ten participants in the first project already concluded (Sealant I) and, in 30 participants in the second, which is now underway (Sealant II).

For the determination of the protein concentration of serine protease (gyroxin) utilized in the finished product, protein dosing was performed via direct reading at 280 nm utilizing a NanoView ${ }^{\circ}$ spectrophotometer (GE Healthcare, USA). This apparatus quantifies the concentration of proteins according to the law of Lambert-Beer [40]. In this manner, the gyroxin quantity sufficient for polymerizing the fibrin contained in $1 \mathrm{~mL}$ of cryoprecipitate was defined for each $2 \mathrm{~mL}$-dose of fibrin sealant. This quantity of polymer should cover an ulcer with a maximum size of $60 \mathrm{~cm}^{2}$. A $1 \mathrm{~mL}$ vial of cryoprecipitate contains, in addition to fibrinogen, the following coagulation factors: factor V, VIII and von Willebrand. The diluent vial contains $0.6 \mathrm{~mL}$ of a stable solution of calcium chloride. The details of this composition are described in the submitted patents [39].

Figures 11 and 12 demonstrate the product packaged for clinical research, with attention to the protocols of the National Health Surveillance Agency (ANVISA) in Brazil, as well as its preparation for application in ulcers of the participants (ethics approval CONEP-CAAE: 19006813.4.1001.5411).

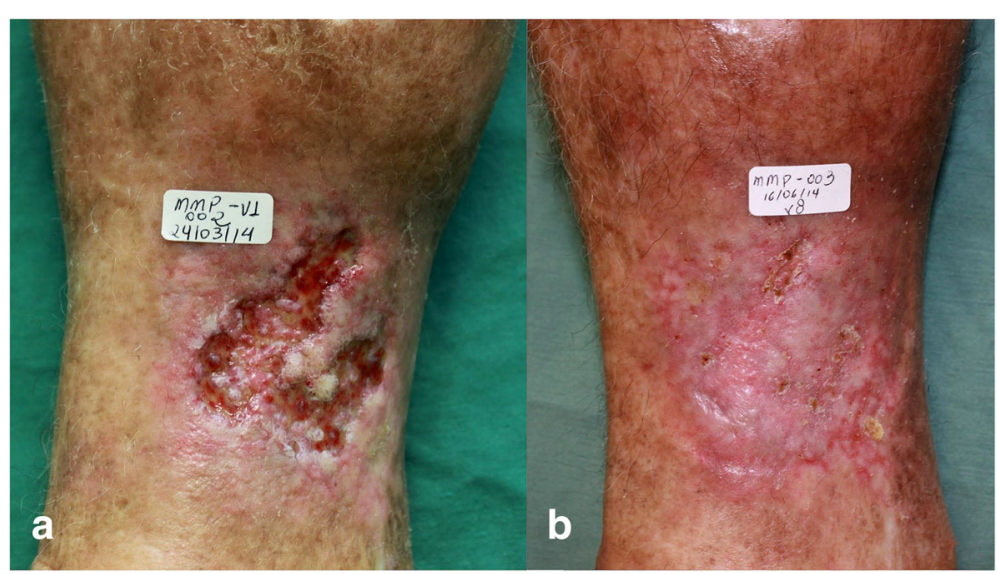

Fig. 13 A 70 year-old female had an ulcer for two years. a Visit 0 - area of the ulcer was $17.1 \mathrm{~cm}^{2}$. b Visit 6 - wound healed 


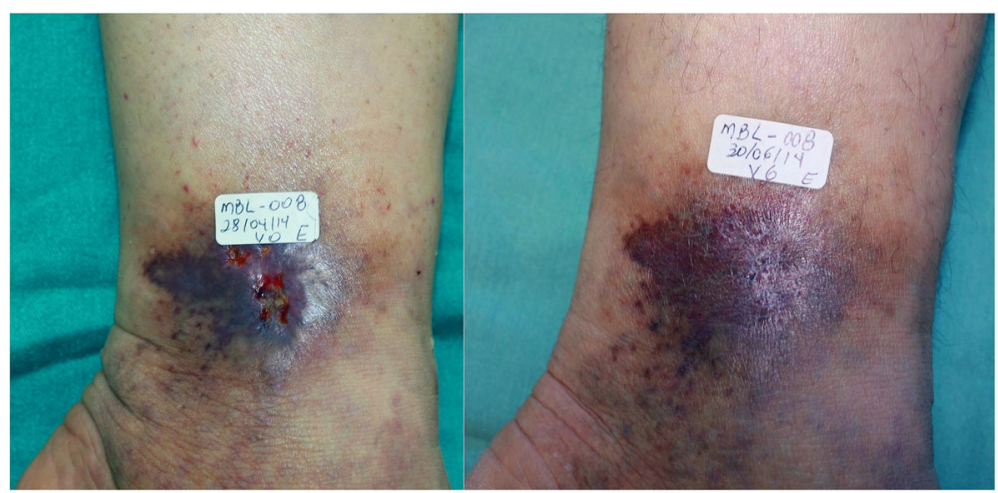

Fig. 14 The 50 year-old patient had an ulcer for 4 months. a Visit 0 - area of the ulcer was $0.3 \mathrm{~cm}^{2}$. b Visit 6 - wound healed

The objectives of the Sealant I project were already achieved, namely: to study safety and most appropriate dose of the new heterologous fibrin sealant for treating chronic venous ulcers.

Figures 13 and 14 show the evolution and ulcers healing in two participants, before (V0) and at the end of treatment.

The new heterologous fibrin sealant is a safe and clinically promising candidate for treating chronic venous ulcers. A multicenter clinical trial, phase II/III, with a larger number of participants will be performed to prove the efficacy of the product [41]. A six-minute video is provided showing an overview of the production and application of the fibrin sealant (Additional file 1) (available at: https://youtu.be/y6ho6M0amA8).

\section{Conclusions}

The homologous commercial fibrin sealant has been used with success since the 1970s. Nowadays, its application has been consolidated in surgical procedures as an efficient method to avoid suturing, decrease recovery time and increase the success rate. Its indications are well defined and proven through a systematic review of studies and meta-analysis [42-45]. Among the unsolved problems, especially in biopharmaceutical production, are the high costs and transmission of infectious diseases by human blood [3, 4]. The new heterologous fibrin sealant, composed primarily of extracted animal products, has low production costs and does not transmit infectious diseases. Standardized for over 20 years by a consortium of Brazilian researchers, several preclinical studies and clinical trials have already been completed. Thus, preclinical trials applying the product in the peripheral nervous and musculoskeletal systems [46-56] and as a scaffold for stem cells have been studied extensively [57-60]. Trials in plastic surgery skin repair [61], periodontal surgery [62-64] and in chronic venous ulcers have also been performed [41, 65]. In addition to treating chronic venous ulcers, further clinical trials, especially ones linked to the nervous system and to skeletal muscle, will allow for a more precise use.

\section{Additional file}

Additional file 1: The video shows a six-min overview of the production and application of the fibrin sealant derived from snake venom and buffalo blood (available at https://youtu.be/y6ho6M0amA8). (DOCX 11 kb)

\begin{abstract}
Abbreviations
2D: Two-dimensional electrophoresis; ANVISA: National Health Surveillance Agency; BSE: Bovine spongiform encephalopathy; CEVAP: Center for the Study of Venoms and Venomous Animals; CJD: Creutzfeldt-Jakob disease (); CRP: C-reactive protein; FDA: U.S. Food and Drug Administration; FFP: Frozen fresh plasma; GMP: Good manufacturing practices; HFS: Heterologous fibrin sealant; IL-1: Interleukin 1; IL-6: Interleukin 6; MCD: Minimum coagulant dose; TNF: Tumor necrosis factor; TSEs: Transmission of spongiform encephalopathies
\end{abstract}

\section{Acknowledgments}

The authors would like to thank Guilherme Shin Iwamoto Haga, Aristides Pavan, Carlos Antonio Caramori, Márcia Tonin Rigotto Carneiro and Natália Bronzato Medolago for their assistance in the present study. Thanks are also due to the Center for the Study of Venoms and Venomous Animals (CEVAP) of UNESP for enabling the publication of this paper (Edital Toxinologia CAPES no. 063/2010, process no. 230.38.006285/2011-21, AUXPE Toxinologia 1219/2011).

\section{Funding}

This study was supported by the São Paulo Research Foundation (FAPESP) (process no. 2009/53846-9 granted to BB and RSF Jr; process no. 2012/081018 granted to RSF Jr and process no. 2014/13299-7 granted to LDS), and to the National Council for Scientific and Technological Development (CNPq) (process no. 563582/2010-3 granted to BB). This work was also supported by the Coordination for the Improvement of Higher Education Personnel (CAPES) through Edital Toxinologia CAPES no. 063/2010, process no. 230.38.006285/2011-21, AUXPE Toxinologia 1219/2011 and by the Department of Science and Technology (DECIT) and the Secretariat of Science, Technology and Strategic Inputs (SCTIE), CNPq process n. 401170/ 2013-6, of the Brazilian Ministry of Health. RSF Jr is a CNPq DTI research fellow (310395/2014-3).

\section{Authors' contributions}

RSF Jr., LCB, SRCSB, MRCS, LDS and LGP searched the databases (PubMed, Scopus, Scielo and Web of Science) and wrote the review. RSF Jr., LPFA and BB corrected the manuscript and prepared the images. All authors read and approved the final manuscript. 


\section{Competing interests}

One of the authors of this article, Dr. Benedito Barraviera, is the Editor-inChief of Journal of Venomous Animals and Toxins including Tropical Diseases. He did not get involved in the peer review process of this manuscript.

\section{Consent for publication}

Written informed consent was obtained from the patients for publication of this study.

\section{Ethics approval and consent to participate}

Part of the research herein presented was approved by the Research Ethics Committee of the Botucatu Medical School (CEP protocol n. 501.232). Moreover, the clinical trials described in the section "The human use of heterologous fibrin sealant" were approved by the National Commission for Ethics on Research (CONEP) and received the Certificate of Presentation for Ethical Appreciation (CAAE) - 19006813.4.1001.5411.

\section{Publisher's Note}

Springer Nature remains neutral with regard to jurisdictional claims in published maps and institutional affiliations.

\section{Author details}

'Graduate Program in Tropical Diseases, Botucatu Medical School, São Paulo State University (UNESP - Univ Estadual Paulista), Botucatu, SP, Brazil. ${ }^{2}$ Center for the Study of Venoms and Venomous Animals (CEVAP), São Paulo State University (UNESP - Univ Estadual Paulista), Botucatu, SP, Brazil. ${ }^{3}$ Department of Dermatology and Radiology, Botucatu Medical School, São Paulo State University (UNESP - Univ Estadual Paulista), Botucatu, SP, Brazil. ${ }^{4}$ CEVAP/ UNESP, Avenida José Barbosa de Barros, 1780, Botucatu, SP CEP 18610-307, Brazil.

Received: 14 January 2017 Accepted: 16 March 2017

Published online: 04 April 2017

\section{References}

1. Spotnitz WD, Burks S. Hemostats, sealants, and adhesives III: a new update as well as cost and regulatory considerations for components of the surgical toolbox. Transfusion. 2012;52(10):2243-55. doi:10.1111/j.1537-2995. 2012.03707.x.

2. Spotnitz WD. Fibrin sealant: The only approved hemostat, sealant, and adhesive - a laboratory and clinical perspective. ISRN Surg. 2014;2014:1-28. doi:10.1155/2014/203943.

3. Hino M, Ishiko O, Honda Kl, Yamane T, Ohta K, Takubo T, et al. Transmission of symptomatic parvovirus B19 infection by fibrin sealant used during surgery. Br J Haematol. 2000;108(1):194-5.

4. Kawamura M, Sawafuji M, Watanabe M, Horinouchi H, Kobayashi K. Frequency of transmission of human parvovirus B19 infection by fibrin sealant used during thoracic surgery. Ann Thorac Surg. 2002;73(4):1098-100.

5. Iuan FC, Thomazini IA, Giannini MJM, Viterbo F, Toscano E, Moraes RA, et al. Reparation of peripheral nerves with fibrin glue prepared from snake venom: preliminary results. Sao Paulo Med J. 1995;113(5):1000-2.

6. Biscola NP, Cartarozzi LP, Ulian-Benitez S, Barbizan R, Castro MV, Spejo AB, et al. Multiple uses of fibrin sealant for nervous system treatment following injury and disease. J Venom Anim Toxins incl Trop Dis. 2017;23:13. doi:10. 1186/s40409-017-0103-1.

7. Thomazini-Santos IA. Fibrin adhesive from snake venom: the effect of adding eaminocaproic acid, tranexamic acid and aprotinin for coaptation of wound in rat skin incisions. J Venom Anim Toxins. 2001;7(1):148-9.

8. Thomazini-Santos IA, Barraviera SRCS, Mendes-Giannini MJS, Barraviera B. Surgical adhesives. J Venom Anim Toxins. 2001;7(2):159-71.

9. Barros LC, Ferreira Jr RS, Barraviera SRCS, Stolf HO, Thomazini-Santos IA, Mendes-Giannini MJS, et al. A new fibrin sealant from Crotalus durissus terrificus venom: applications in medicine. J Toxicol Environ Health B Crit Rev. 2009;12(8):553-71.

10. Gasparotto VPO, Landim-Alvarenga FC, Oliveira ALR, Simões GF, Lima-Neto JF, Barraviera B, et al. A new fibrin sealant as a three-dimensional scaffold candidate for mesenchymal stem cells. Stem Cell Res Ther. 2014;5(3):78.

11. Seki C, Vidal JC, Barrio A. Purification of gyroxin from a South American rattlesnake (Crotalus durissus terrificus) venom. Toxicon. 1980;18(3):235-47.
12. Raw I, Rocha MC, Esteves MI, Kamiguti AS. Isolation and characterization of a thrombin-like enzyme from the venom of Crotalus durissus terrificus. Braz J Med Biol Res. 1986;19(3):333-8.

13. Bercovici D, Chudziniski AM, Dias WO, Esteves Ml, Hiraichi E, Oishi NY, et al. A systemic fractionation of Crotalus durissus terrificus venom. Mem Inst Butantan. 1987:49(3):69-78.

14. Rawling ND, Tolle DP, Barret AJ. Evolutionary families of peptidase inhititors. Biochem J. 2004;378(Pt 3):705-16.

15. Andrews RK, Gardiner EE, Berndt MC. Snake venom toxins affecting platelet function. Methods Mol Biol. 2004;273:335-48.

16. de Oliveira DGL, Murakami MT, Cintra ACO, Franco JJ, Sampaio SV, Arni RK. Functional and structural analysis of two fibrinogen-activating enzymes isolated from the venoms of Crotalus durissus terrificus and Crotalus durissus collilineatus. Acta Biochim Biophys Sin Shanghai. 2009;41(1):21-9. doi:10. 1093/abbs/gmn003.

17. Buchi AT. Purification, characterization, crystallization and theoretical molecular modeling of gyroxin fraction from Crotalus durissus terrificus venom (Laurenti, 1768). J Venom Anim Toxins incl Trop Dis. 2010;16(2):389-90.

18. Barros LC, Soares AM, Costa FL, Rodrigues VM, Fuly AL, Giglio JR, et al. Biochemical and biological evaluation of gyroxin isolated from Crotalus durissus terrificus venom. J Venom Anim Toxins incl Trop Dis. 2011;17(1):23-33.

19. O'Shaughnessy DF, Atterbury C, Bolton Maggs P, Murphy M, Thomas D, Yates $\mathrm{S}$, et al. Guidelines for the use of fresh-frozen plasma, cryoprecipitate and cryosupernatant. Br J Haematol. 2004;126(1):11-28. doi:10.1111/j.13652141.2004.04972.x

20. Nascimento B, Goodnough LT, Levy JH. Cryoprecipitate therapy. Br J Anaesth. 2014;113(6):922-34. doi:10.1093/bja/aeu158.

21. Thomazini-Santos IA, Giannini MJSM, Toscano E, Machado PEA, Lima CRG, Barraviera B. The evaluation of clotting time in bovine thrombin, Reptilase, and thrombin-like fraction of Crotalus durissus terrificus venom using bovine, equine, ovine bubaline and human cryoprecipitates. J Venom Anim Toxins. 1998;4(2):120-36.

22. Associação Brasileira de Criadores de Búfalos. Available in 10 Aug 2016 at http://www.bufalo.com.br/home/

23. Ministério da Agricultura, Pecuária e Abastecimento. Plano de ação para febre aftosa. Ministério da Agricultura, Pecuária e Abastecimento. Secretaria de Defesa Agropecuária - Brasília: MAPA/SDA/DAS; 2009. p. 96.

24. Ministério da Agricultura, Pecuária e Abastecimento. Programa Nacional de Controle e Erradicação da Brucelose e da Tuberculose Animal (PNCEBT), Brasília: MAPA/SDA/DAS; 2006. p. 188.

25. Ministério da Agricultura, Pecuária e Abastecimento Controle da Raiva dos herbívoros - Brasília; 2005. p. 104

26. Barros CSL, Marques GHF. Procedimentos para o diagnóstico das doenças do sistema nervoso central de bovinos. Brasília; 2003. p. 50.

27. Ministério da Agricultura, Pecuária e Abastecimento. Manual de Legislação: programas nacionais de saúde animal do Brasil. Ministério da Agricultura, Pecuária e Abastecimento. Secretaria de Defesa Agropecuária. Brasília: Departamento de Saúde Animal; 2009.

28. Manual de procedimentos para a atenção às ocorrências de febre aftosa e outras enfermidades vesiculares. Projeto BID/PANAFTOSA - OPAS/OMS para os países do MERCOSUL Ampliado. Rio de Janeiro: PANAFTOSA - OPAS/ OMS; 2007. p. 144

29. Zoonoses and veterinary public health. World Health Organization. Available in 10 Aug 2016 at http://www.who.int/zoonoses/diseases/prion_diseases/en/

30. da Silva DA F, Biscola NP, Souza RMF, Caetano DA, Denadai JC, Sartori MMP, et al. Carbon-13 and Nitrogen-15 turnover in serum of bubaline donors of biological material for medical use. Toxicon. 2012;60(2):117.

31. Fossato da Silva D, Biscola NP, dos Santos LD, Sartori MMP, Denadai JC, Silva ET, et al. Detecting animal by-product intake using stable isotope ratio mass spectrometry (IRMS). Vet J. 2016;217:119-25. doi:10.1016/j.tvjl. 2016.10.002.

32. Petersen $\mathrm{HH}$, Nielsen JP, Heegaard PMH. Application of acute phase protein measurements in veterinary clinical chemistry. Vet Res. 2004;35(2):163-87.

33. Petersen $\mathrm{HH}$, Ersbø\|l AK, Jensen CS, Nielsen JP. Serum-haptoglobin concentration in Danish slaughter pigs of different health status. Prev Vet Med. 2002;54(4):325-35

34. Gruys E, Toussaint MJM, Niewold TA, Koopmans SJ. Acute phase reaction and acute phase proteins. J Zhejiang Univ Sci B. 2005;6(11):1045-56.

35. Gutierrez AM, Martinez-Subiela S, Eckersall PD, Cerón JJ. C-reactive protein quantification in porcine saliva: a minimally invasive test for pig health monitoring. Vet J. 2009;181(3):261-5. 
36. Ferreira Jr RS, Almeida RAMB, Barraviera SRCS, Barraviera B. Historical perspective and human consequences of africanized bee stings in the Americas. J Toxicol Environ Health B Crit Rev. 2012;15(2):97-108.

37. Barraviera B, Lomonte B, Tarkowski A, Hanson LA, Meira DA. Acute-phase reactions, including cytokines, in patients bitten by Bothrops and Crotalus snakes in Brazil. J Venom Anim Toxins. 1995:1(1):11-22.

38. Tabb DL. Quality assessment for clinical proteomics. Clin Biochem. 2013; 46(6):411-20.

39. Ferreira Jr RS. Autologous or heterologous fibrin sealant scaffold: which is the better choice? J Venom Anim Toxins incl Trop Dis. 2014;20:31. doi:10. 1186/1678-9199-20-31

40. Mäntele W, Deniz E. UV-VIS absorption spectroscopy: Lambert-Beer reloaded. Spectrochim Acta A Mol Biomol Spectrosc. 2017;173:965-8.

41. Abbade LPF, Barraviera SRCS, Silvares MRC, Carneiro MTR, Medolago NB, Ferreira Jr RS, et al. A new fibrin sealant derived from snake venom candidate to treat chronic venous ulcers. J Am Acad Dermatol. 2015;72(5): AB271. Supplement 1.

42. Li J, Li HB, Zhai XC, Qin-Lei, Jiang XQ, Zhang ZH. Topical use of topical fibrin sealant can reduce the need for transfusion, total blood loss and the volume of drainage in total knee and hip arthroplasty: A systematic review and meta-analysis of 1489 patients. Int J Surg. 2016;36(Pt A):127-37. doi:10. 1016/j.jijsu.2016.10.022.

43. Rogers AC, Turley LP, Cross KS, McMonagle MP. Meta-analysis of the use of surgical sealants for suture-hole bleeding in arterial anastomoses. $\mathrm{Br} J$ Surg. 2016;103(13):1758-67. doi:10.1002/bjs.10308.

44. Brustia R, Granger B, Scatton O. An update on topical haemostatic agents in liver surgery: systematic review and meta analysis. J Hepatobiliary Pancreat Sci. 2016;23(10):609-21. doi:10.1002/jhbp.389.

45. Weldrick C, Bashar K, O'Sullivan TA, Gillis E, Clarke Moloney M, Tang TY, et al. A comparison of fibrin sealant versus standard closure in the reduction of postoperative morbidity after groin dissection: A systematic review and metaanalysis. Eur J Surg Oncol. 2014;40(11):1391-8. doi:10.1016/j.ejso.2014.07.034.

46. Barbizan R, Castro MV, Rodrigues AC, Barraviera B, Ferreira Jr RS, Oliveira ALR. Motor recovery and synaptic preservation after ventral root avulsion and repair with a fibrin sealant derived from snake venom. PLoS One. 2013; 8(5), e63260.

47. Spejo AB, Carvalho JL, Goes AM, Oliveira AL. Neuroprotective effects of mesenchymal stem cells on spinal motoneurons following ventral root axotomy: synapse stability and axonal regeneration. Neuroscience. 2013; 250:715-32.

48. Benitez SU, Barbizan R, Spejo AB, Ferreira Jr RS, Barraviera B, Goes AM, et al. Synaptic plasticity and sensory-motor improvement following fibrin sealant dorsal root reimplantation and mononuclear cell therapy. Front Neuroanat. 2014;8:96.

49. Barbizan R, Castro MV, Barraviera B, Ferreira Jr RS, Oliveira ALR. Influence of delivery method on neuroprotection by bone marrow mononuclear cell therapy following ventral root reimplantation with fibrin sealant. PLoS One. 2014;9(8), e105712.

50. Barbizan R, Castro MV, Ferreira Junior RS, Barraviera B, Oliveira ALR. Longterm spinal ventral root reimplantation, but not bone marrow mononuclear cell treatment, positively influences ultrastructural synapse recovery and motor axonal regrowth. Int J Mol Sci. 2014;15(11):19535-51.

51. Buchaim RL, Andreo JC, Barraviera B, Ferreira Jr RS, Buchaim DV, Rosa Jr GM, et al. Effect of low-level laser therapy (LLLT) on peripheral nerve regeneration using fibrin glue derived from snake venom. Injury. 2015;46(4):655-60.

52. Castro MV, Barbizan R, Ferreira Jr RS, Barraviera B, Oliveira ALR. Direct spinal ventral root repair following avulsion: effectiveness of a new heterologous fibrin sealant on motoneuron survival and regeneration. Neural Plast. 2016; 2016:2932784

53. Biscola NP, Cartarozzi LP, Ferreira Jr RS, Barraviera B, Oliveira ALR. Longstanding motor and sensory recovery following acute fibrin sealant based neonatal sciatic nerve repair. Neural Plast. 2016;2016:9028126.

54. Buchaim DV, Rodrigues A de C, Buchaim RL, Barraviera B, Ferreira Jr RS, Jr $\mathrm{GM}$, et al. The new heterologous fibrin sealant in combination with lowlevel laser therapy (LLLT) in the repair of the buccal branch of the facial nerve. Lasers Med Sci. 2016;31(5):965-72.

55. de Oliveira Gonçalves JB, Buchaim DV, de Souza Bueno CR, Pomini KT, Barraviera B, Ferreira Jr RS, et al. Effects of low-level laser therapy on autogenous bone graft stabilized with a new heterologous fibrin sealant. J Photochem Photobiol B. 2016;162:663-8.
56. Spejo AB, Chiarotto GB, Ferreira Jr RS, Barraviera B, Oliveira ALR. Effects of mesenchymal stem cell and fibrin sealant treatment following spinal cord injury. 12th International Congress of Cell Biology (ICCB 2016), Vol. 1, Praga, República Tcheca; 2016. p.1-3

57. de Barros CN, Miluzzi Yamada AL, Ferreira Jr RS, Barraviera B, Hussni CA, de Souza JB, et al. A new heterologous fibrin sealant as a scaffold to cartilage repair - Experimental study and preliminary results. Exp Biol Med (Maywood). 2016;241(13):1410-5. doi:10.1177/1535370215597192.

58. Machado EG, Issa JPM, Figueiredo FAT, Santos GR, Galdeano EA, Alves MC, et al. A new heterologous fibrin sealant as scaffold to recombinant human bone morphogenetic protein-2 (rhBMP-2) and natural latex proteins for the repair of tibial bone defects. Acta Histochem. 2015;117(3):288-96.

59. Cunha MR, Menezes FA, Santos GR, Pinto CAL, Barraviera B, Martins VCA, et al. Hydroxyapatite and a new fibrin sealant derived from snake venom as scaffold to treatment of cranial defects in rats. Mat Res. 2015:18(1):196-203.

60. Cartarozzi LP, Spejo AB, Ferreira Jr RS, Barraviera B, Duek D, Carvalho JL, et al. Mesenchymal stem cells engrafted in a fibrin scaffold stimulate Schwann cell reactivity and axonal regeneration following sciatic nerve tubulization. Brain Res Bull. 2015;112:14-24.

61. Stolf HO. The use of fibrin adhesive derived from snake venom and the evaluation of skin grafting using skin from the patient's nasolabial fold. J Venom Anim Toxins. 1999;5(2):227

62. Barbosa MDS, Greghi SLA, Passanezi E. Fibrin adhesive derived from snake venom in periodontal surgery. J Periodontol. 2007;78(10):2026-31.

63. Barbosa MD, Stipp AC, Passanezi E, Greghi SL. Fibrin adhesive derived from snake venom in periodontal surgery: histological analysis. J Appl Oral Sci. 2008;16(5):310-5.

64. Chiquito GCM. Comparison between suture and fibrin adhesive derived from snake venom for fixation of connective tissue graft in correction of marginal tissue recession. J Venom Anim Toxins incl Trop Dis. 2007;13(2):559.

65. Gatti MAN, Vieira LM, Barraviera B, Barraviera SRCS. Treatment of venous ulcers with fibrin sealant derived from snake venom. J Venom Anim Toxins incl Trop Dis. 2011;17(2):226-9.

\section{Submit your next manuscript to BioMed Central and we will help you at every step:}

- We accept pre-submission inquiries

- Our selector tool helps you to find the most relevant journal

- We provide round the clock customer support

- Convenient online submission

- Thorough peer review

- Inclusion in PubMed and all major indexing services

- Maximum visibility for your research

Submit your manuscript at www.biomedcentral.com/submit 